\title{
ANALISIS PENGGUNAAN DAUN NILAM KERING DALAM PROSES \\ PENYULINGAN MINYAK NILAM DI KABUPATEN ACEH JAYA
}

(Analysis Added Value Of Using The Dried Leaves Patchouli Of Refineries In Process

Patchouli Oil In Aceh Jaya)

\author{
Maisarah $^{1}$, Agustina Arida ${ }^{1}$, Irwan A. Kadir $^{*}$ \\ ${ }^{1}$ Program Studi Agribisnis, Fakultas Pertanian, Universitas Syiah Kuala
}

\begin{abstract}
Abstrak - Tanaman nilam merupakan salah satu tanaman penghasil minyak atsiri di Indonesia. Penyulingan minyak nilam di Kabupaten Aceh Jaya merupakan salah satu cara untuk meningkatkan nilai tambah dari daun nilam kering yang dilakukan oleh petani nilam. Penelitian ini bertujuan untuk mengetahui persentase rentabilitas dan persentase rasio nilai tambah yang diperoleh dari usaha penyulingan minyak nilam di Kabupaten Aceh Jaya. Data yang digunakan adalah data primer dan data sekunder. Metode analisis yang digunakan adalah dengan menggunakan metode kuantitatif. Hasil penelitian menunjukkan bahwa Usaha penyulingan minyak nilam menguntungkan bagi petani karena persentase rentabilitas yang diperoleh sebesar $31,7 \%$. Berarti bahwa persentase rentabilitas > tingkat bunga yang berlaku. Adapun tingkat bunga yang berlaku $(6,75 \%)$. Usaha penyulingan minyak nilam memberikan nilai tambah yang diperoleh adalah bersifat positif yaitu $\mathrm{Rp} 6.630 / \mathrm{Kg}$ dengan rasio nilai tambah $84,75 \%$ yang berarti selisih antara penjualan daun nilam kering dengan penjualan minyak nilam berbeda sebesar $84,75 \%$. Berarti bahwa nilai tambah yang diperoleh petani adalah tinggi, karena rasio nilai tambah $>40 \%$.
\end{abstract}

Kata Kunci: Daun Nilam Kering, Minyak Nilam, Rentabilitas, Nilai Tambah.

\begin{abstract}
Patchouli is one of the essential oil producing plants in Indonesia. Patchouli oil refinery in the district of Aceh Jaya is one way to increase the added value of the dried patchouli leaves collected by the farmers patchouli. This study aims to determine the percentage of earnings, and the percentage ratio of the added value derived from patchouli oil refining business in the district of Aceh Jaya. The data used are primary data and secondary data. The analytical method used is to use quantitative methods. The results showed that the patchouli oil refining businesses profitable for farmers because of the percentage of earnings gained $31.7 \%$. Means that the percentage of profitability $>$ the prevailing interest rate. The applicable interest rate $(6.75 \%)$. Patchouli oil refining business adds value obtained is positive, namely Rp6.630 / kg with added value ratio $84.75 \%$, which means the difference between the sale of dried patchouli leaves with different patchouli oil sales amounted to $84.75 \%$. Means that the added value of the farmers is high, because the ratio of added value> $40 \%$.
\end{abstract}

Keywords: Dried Leaves Patchouli, Patchouli oil, Profitability, Value Added.

\section{PENDAHULUAN}

Tanaman nilam (Pogostemon cablin Benth) merupakan salah satu tanaman penghasil minyak yang terpenting di Indonesia. Dalam dunia perdagangan minyak nilam dikenal dengan nama patchouli oil yang banyak digunakan sebagai bahan baku, bahan pencampur dan fiksasif 
(pengikat wangi-wangian) dalam industri parfum, farmasi dan kosmetika(Grieve, 2003 dalam Melati, 2008).

Indonesia merupakan negara tropis yang kaya akan komoditas perkebunan salah satunya adalah komoditas Nilam Aceh. Nilam Aceh pada umumnya tidak berbunga, sehingga daun terus tumbuh tidak terbatas. Sifat pertumbuhan tanaman yang demikian, akan menghasilkan daun yang berbagai tingkat kematangan, mulai dari daun pucuk sampai daun yang telah tua mengering (Hobir, 2002).

Nilam ini merupakan jenis nilam yang banyak dibudidadayakan untuk tujuan produksi minyak dengan kadar minyak tinggi yaitu $>2,5 \%$, kualitas minyak memenuhi standar mutu perdagangan yang yang dicirikan dengan kadar patchouli alcohol yang tinggi, rentan terhadap nematoda dan tidak berbunga (Budi, 2009).

Di Aceh yaitu daerah pantai barat selatan mulai ditanam pada tahun 1909. Penanaman nilam di Aceh begitu luas sehingga pernah mencapai 2.470 Ha pada tahun 2015. Hingga kini nilam di Aceh menjadi andalan dengan kualitas mutu terbaik yang berasal dari Kabupaten Aceh Jaya, Calang. Namun hasil wawancara dengan petani nilam menyatakan bahwa saat ini minat petani untuk mengolah nilam mulai berkurang, hal ini disebabkan bahwa harga jual minyak nilam setempat terlampau rendah yaitu mencapai $\mathrm{Rp} 600.000 / \mathrm{Kg}$, sedangkan biaya bahan-bahan pendukung pengolahan minyak nilam meningkat sehingga nilai tambah yang didapatkan petani rendah. Kabupaten Aceh Jaya merupakan salah satu penghasil nilam di Aceh, hal ini dapat dilihat pada Tabel 1.

Tabel 1. Luas Tanam, Luas Panen, Produksi dan Produktivitas Nilam Menurut Kabupaten di provinsi Aceh 2015

\begin{tabular}{|l|l|c|c|c|c|}
\hline No & \multicolumn{1}{|c|}{ Kabupaten } & $\begin{array}{c}\text { Luas } \\
\text { Tanam (Ha) }\end{array}$ & $\begin{array}{c}\text { Luas } \\
\text { Panen } \\
\text { (Ha) }\end{array}$ & $\begin{array}{c}\text { Produksi Daun } \\
\text { Nilam Basah } \\
\text { (Ton) }\end{array}$ & $\begin{array}{c}\text { Produksi Minyak } \\
\text { Nilam (Kg) }\end{array}$ \\
\hline 1 & Aceh Singkil & 48 & 43 & 731 & 1.015 \\
\hline 2 & Aceh Selatan & 200 & 196 & 3.332 & 4.628 \\
\hline 3 & Aceh Tenggara & 712 & 535 & 9.095 & 12.632 \\
\hline 4 & Aceh Tengah & 9 & 4 & 68 & 94 \\
\hline 5 & Aceh Barat & 89 & 89 & 1.513 & 2.101 \\
\hline 6 & Bireun & 42 & 34 & 578 & 803 \\
\hline 7 & Aceh Utara & 132 & 125 & 2.125 & 2.951 \\
\hline 8 & Gayo Lues & 863 & 834 & 14.178 & 19.692 \\
\hline 9 & Aceh Jaya & 500 & 440 & 7.480 & 10.389 \\
\hline 10 & Aceh Barat Daya & 50 & 42 & 714 & 992 \\
\hline 11 & Subulussalam & 19 & 8 & 136 & 189 \\
\hline 12 & Aceh Besar & 118 & 93 & 1.581 & 2.196 \\
\hline & Jumlah & 2.810 & 2.470 & 41.990 & 58.319 \\
\hline
\end{tabular}

Sumber: Dinas Perkebunan Aceh, 2015

Dari tabel diatas dapat dilihat bahwa Aceh Jaya memiliki luas lahan urutan ketiga setelah Kabupaten Gayo Lues dan Aceh Tenggara dengan luas 500 Ha. Dari luas tanam 
tersebut terbagi di enam kecamatan, yaitu Kecamatan Jaya, Sampoiniet, Setia bakti, Krueng sabee, Panga dan Teunom.

Tabel 2. Luas Tanam, Produksi dan Produktivitas Tanaman Nilam Menurut Kecamatan di Kabupaten Aceh Jaya 2015

\begin{tabular}{|c|l|c|c|c|}
\hline No & \multicolumn{1}{|c|}{ Kecamatan } & $\begin{array}{c}\text { Luas Tanam } \\
(\mathrm{Ha})\end{array}$ & Produksi (Kg) & Produksi Minyak (Kg) \\
\hline 1 & Teunom & 64 & 1.100 .800 & 15.289 \\
\hline 2 & Panga & 65 & 1.118 .000 & 15.528 \\
\hline 3 & Krueng Sabee & 105 & 1.806 .000 & 25.083 \\
\hline 4 & Setia Bakti & 66 & 1.135 .200 & 15.767 \\
\hline 5 & Sampoiniet & 35 & 602.000 & 8.361 \\
\hline 6 & Jaya & 24 & 412.800 & 4.733 \\
\hline 7 & Indra Jaya & 20 & 344.000 & 10.750 \\
\hline 8 & Darul Hikmah & 45 & 774.000 & 18.156 \\
\hline 9 & Pasie Raya & 76 & 1.307 .200 & 119.444 \\
\hline \multicolumn{2}{|c|}{ Jumlah } & 500 & 8.600 .000 & \\
\hline
\end{tabular}

Sumber: Dinas Perkebunan Kabupaten Aceh Jaya, 2015

Dari tabel diatas dapat dilihat bahwa luas tanam tanaman nilam terluas terdapat di Kecamatan Krueng Sabee, yaitu mencapai $105 \mathrm{Ha}$, sedangkan luas tanam tersempit terdapat di Kecamatan Indra Jaya, yaitu $20 \mathrm{Ha}$. Dari hasil wawancara dengan karyawan dinas perkebunan Aceh Jaya bahwa minat masyarakat Aceh Jaya untuk menanam dan mengolah nilam sudah berkurang yaitu dari 1.467 petani (2012) menjadi 1.115 petani (2015).

Nilai tambah adalah bertambahnya nilai terhadap suatu komoditas karena melalui proses pengolahan, penyimpanan, maupun pengangkutan dalam suatu produksi yang diperoleh dari selisih antara nilai produk dengan nilai biaya input tidak termasuk upah tenaga kerja. Menurut Suryana (1990), peningkatan nilai tambah dari suatu produk agribisnis pada dasarnya tidak terlepas dari aplikasi teknologi yang tepat dan sistem manajemen yang professional. Besarnya nilai tambah yang tergantung dari teknologi digunakan dalam proses produksi dan adanya perlakuan lebih lanjut terhadap produk yang dihasilkan. Suatu perusahaan dengan teknologi yang baik akan menghasilkan produk dengan kualitas yang lebih baik pula, sehingga harga produk olahan akan lebih tinggi dan akhirnya akan memperbesar nilai tambah yang diperoleh.

Untuk meningkatkan nilai tambah dari nilam dibutuhkan proses pengolahan atau prosesing yang merupakan unsur dari agribisnis mengingat dari ketahanan produk pertanian dan harga jual, maka inovasi dan kreativitas untuk menjadikan produk pertanian laku dengan harga tinggi sehingga memberikan keuntungan bagi petani nilam yaitu dengan pengolahan nilam menjadi minyak nilam. Dalam menyuling daun nilam kering, petani harus menunggu 34 jam untuk menghasilkan $1,2 \mathrm{Kg}$ minyak nilam dengan $72 \mathrm{Kg}$ daun kering. Penyulingan biasanya dilakukan pada malam hari dengan pertimbangan bahwa pada malam hari pemuaian rendah. Dengan rendemennya $1,7 \%$.

Untuk mengetahui kelayakan suatu usaha dapat dilakukan melalui pendekatan rentabilitas. Rentabilitas suatu usaha menunjukkan perbandingan antara laba dengan modal yang menunjukkan kemampuan suatu usaha untuk menghasilkan laba dalam satu periode. 
Meskipun harga jual minyak nilam mencapai $\mathrm{Rp} 600.000 / \mathrm{Kg}$, tetapi bahan-bahan yang dibutuhkan untuk proses penyulingan ini juga sangat banyak dan membutuhkan biaya yang tinggi serta upah tenaga kerja. Hal ini menimbulkan pertanyaan apakah segala biaya yang dikeluarkan dan harga jual hanya dengan Rp 600.000 akan dapat meningkatkan nilai tambah ? Dari pertanyan atau permasalahan di atas, maka peneliti tertarik untuk melakukan penelitian dengan menganalisis nilai tambah proses pengolahan minyak nilam Di Kabupaten Aceh Jaya.

Berdasarkan latar belakang yang telah diuraikan diatas, dapat diidentifikasikan permasalahan berikut, yaitu: 1) Berapakah persentase rentabilitas yang diperoleh dari usaha penyulingan minyak nilam, 2) Berapakah persentase rasio nilai tambah yang diperoleh petani dalam usaha peyulingan minyak.

Tujuan penelitian ini adalah untuk mengetahui persentase rentabilitas dan rasio nilai tambah yang diperoleh petani nilam dari usaha penyulingan minyak nilam di Kabupaten Aceh Jaya.

\section{METODOLOGI PENELITIAN}

Penelitian ini dilakukan di Kabupaten Aceh Jaya. Penentuan lokasi tersebut dilakukan secara purposive sampling, yaitu berdasarkan pertimbangan bahwa Aceh Jaya merupakan daerah yang memiliki lahan nilam terluas ketiga setelah Gayo Lues dan Aceh Tenggara. Dari 9 Kecamatan yang ada di Kabupaten Aceh Jaya, Kecamatan Sampoiniet dan Krueng Sabee terpilih sebagai lokasi penelitian. Pengambilan sampel untuk lokasi dilakukan secara nonprobability yaitu menggunakan teknik purposive sampling yaitu dengan pertimbangan bahwa lokasi ini merupakan daerah yang memiliki produktivitas tertinggi dan lahan terluas.Adapun objek dari penelitian ini adalah petani nilam yang memiliki ketel dan lahan usaha nilam. Ruang lingkup penelitian terbatas pada persentase rentabilitas usaha penyulingan minyak nilam dan persentase rasio nilai tambah dari usaha penyulingan minyak nilam di Kabupaten aceh Jaya. Populasi dalam penelitian ini adalah petani nilam yang memiliki ketel yang terdapat di Kabupaten Aceh Jaya. Adapun populasi dalam penelitian ini berjumlah 6 KK yaitu 2 KK di Kecamatan Sampoiniet dan 4 KK di Kecamatan Krueng Sabee. Pengambilan sampel dari masing-masing petani nilam dengan menggunakan teknik sampel jenuh yaitu pengambilan sampel secara keseluruhan populasi yaitu $6 \mathrm{KK}$ petani nilam yang memiliki ketel penyulingan dan memiliki lahan milik pribadi.

Jenis data yang dikumpulkan dalam penelitian ini adalah data primer dan data sekunder. Pengumpulan data primer dilakukan dengan mewawancarai responden (petani nilam) dengan menggunakan kuisioner. Sedangkan pengumpulan data sekunder diperoleh dari berbagai sumber, seperti BPS (Badan Pusat Statistik), dinas perkebunan, jurnal dan literatur yang relevan dengan penelitian ini.

Metode analisis yang digunakan penelitian ini adalah metode deskriptif kuantitatif. Adapun rumus yang digunakan untuk menghitung persentase rentabilitas dan rasio nilai tambah yaitu sebagai berikut:

\section{a. Pendapatan}

$\pi=\mathrm{TR}-\mathrm{TC}$ (Soekartawi, 1995)

Keterangan :

$\Pi=$ Total pendapatan yang diterima petani

$\mathrm{TR}=$ Total penerimaan 
$\mathrm{TC}=$ Total biaya

\section{b. Breake Event Point}

BEP Volume Produksi $=\frac{\text { Total Biaya }}{\text { Harga Jual }} \ldots \ldots \ldots . .$. Cahyono (2003)

BEP Harga Produksi $\quad=\frac{\text { Total Biaya }}{\text { Total Produksi }} \ldots \ldots \ldots \ldots$. Cahyono $(2003)$

\section{c. Rentabilitas}

Rentabilitas $=\frac{L}{M} \times 100 \%$................ Riyanto (1999)

Dimana :

$\mathrm{L}$ = Jumlah pendapatan bersih yang diperoleh selama satu periode tertentu

M = Modal (Biaya Produksi)

Perhitungan rentabilitas digunakan untuk mengukur besarnya penggunaan modal didalam suatu perausahaan dimana laba yang diperoleh dihitung dalam satuan persen dengan keputusan sebagai berikut :

1. Jika rentabilitas > tingkat bunga modal yang berlaku, maka usaha tersebut akan menguntungkan untuk diusahakan.

2. Jika rentabilitas < tingkat bunga, maka usaha tersebut belum menguntungkan untuk diusahakan.

\section{d. Analisis Nilai Tambah}

$N T_{D N K}=\pi_{M N}-\pi_{D N K} \ldots \ldots \ldots \ldots . .($ Kairupan, 2015)

Keterangan :

$\mathrm{NT}_{\mathrm{DNK}}=$ Nilai Tambah Daun Nilam Kering $(\mathrm{Rp})$

$\pi_{D N K} \quad=$ Pendapatan dari daun nilam kering dalam satuan $\mathrm{Rp}$

$\pi_{M N}=$ Pendapatan dari minyak nilam dalam satuan $\mathrm{Rp}$

Untuk menghitung persentase yaitu menggunakan rumus :

$$
N T_{D N K}(\%)=\frac{N T_{D N K}}{\pi_{D N K}} \times 100 \%
$$

Menurut Hubeis (1997), rasio nilai tambah dapat digolongkan menjadi 3 yakni dikatakan rendah jika (<15\%), sedang jika berkisar $(15 \%$ - $40 \%)$ dan tinggi jika $(>40 \%)$.

\section{Karakteristik Responden}

\section{HASIL DAN PEMBAHASAN}

Karakteristik responden dalam penelitian ini terdiri dari umur, pendidikan formal dan tingkat pengalaman. Tingkat umur mempunyai pengaruh terhadap kemampuan bekerja yang sangat berpengaruh pada pendapatan petani nilam. Kelompok umur, tingkat pendidikan dan tingkat pengalaman petani dilokasi penelitian dapat dilihat pada Tabel 3.

Dari Tabel 3 diketahui bahwa tingkat pendidikan tidak mempengaruhi petani untuk menyuling minyak nilam, sedangkan dari segi umur kita ketahui bahwa seluruh petani nilam berada pada umur produktif dan rata-rata pengalaman adalah $>5$ tahun. Hal ini dapat disimpulkan bahwa petani yang menyuling minyak nilam adalah petani yang memiliki umur produkdif dan tingkat pengalaman yang relatif lama.

Tabel 3. Karakteristik Responden

\begin{tabular}{|l|l|l|l|} 
Katagori & Kelompok (Tahun) & Jumlah (Orang) & Persentase (\%) \\
\hline
\end{tabular}




\begin{tabular}{|c|c|c|c|}
\hline \multirow{7}{*}{ Umur } & $0-10$ & 0 & 0 \\
\hline & $11-20$ & 0 & 0 \\
\hline & $21-30$ & 2 & 33 \\
\hline & $31-40$ & 3 & 50 \\
\hline & $41-50$ & 1 & 17 \\
\hline & $51-60$ & 0 & 0 \\
\hline & $>60$ & 0 & 0 \\
\hline \multicolumn{2}{|c|}{ Jumlah } & 6 & 100 \\
\hline \multirow{3}{*}{ Pendidikan } & $<6$ & 2 & 33,3 \\
\hline & $7-9$ & 3 & 50 \\
\hline & $10-12$ & 1 & 16,7 \\
\hline \multicolumn{2}{|c|}{ Jumlah } & 6 & 100 \\
\hline \multirow[t]{3}{*}{ Pengalaman } & $0-5$ & 1 & 16,7 \\
\hline & $6-10$ & 4 & 66,6 \\
\hline & $>10$ & 1 & 16,7 \\
\hline \multicolumn{2}{|c|}{ Jumlah } & 6 & 100 \\
\hline
\end{tabular}

Sumber : Data Primer (Diolah), 2016.

\section{Penggunaan Biaya Dalam Penyediaan Bahan Baku (Daun Nilam Kering)}

Penggunaan biaya dalam memproduksi bahan baku sama dengan arus pengeluaran yaitu seluruh biaya yang dikeluarkan petani dalam memproduksi atau penyediaan bahan baku. Penggunaan biaya ini terdiri dari biaya tetap dan biaya variabel.

\section{Biaya Tetap}

Biaya tetap adalah seluruh biaya yang dikeluarkan tidak tergantung pada jumlah output yang dihasilkan. Penggunaan biaya tetap dapat dilihat pada Tabel 4.

Tabel 4. Jumlah Biaya Tetap Dalam Penyediaan Bahan Baku (Daun Nilam Kering)

\begin{tabular}{|c|l|r|}
\hline No & \multicolumn{1}{|c|}{ Peralatan } & Biaya Penyusutan (Rp/Periode) \\
\hline 1 & Sadap & 9.445 \\
\hline 2 & Parang & 4.000 \\
\hline 3 & Cangkul & 8.000 \\
\hline 4 & Bronjong & 20.000 \\
\hline 5 & Terpal & 10.467 \\
\hline 6 & Spayer & 73.333 \\
\hline Jumlah & & 125.225 \\
\hline
\end{tabular}

Sumber : Data Primer (Diolah), 2016

Dari Tabel diatas dapat dilihat bahwa biaya penyusutan tertinggi ada pada alat penyemprotan atau spayer yaitu mencapai Rp 73.333/Periode. Hal ini disebabkan karena umur ekonomis yang hanya berumur 3 tahun, sedangkan untuk alat-alat lain umur ekonomisnya mencapai 5 tahun.

\section{Biaya Variabel}

Biaya variabel adalah biaya-biaya yang dikeluarkan tergantung pada jumlah produksi yang dihasilkan. Adapun komponen biaya variabel antar lain adalah biaya penyediaan bibit, biaya bahan penunjang dan upah tenaga kerja.

\section{Biaya Penyediaan Bibit}

Bibit merupakan bahan utama yang digunakan untuk menghasilkan bahan baku daun nilam. Untuk memperoleh daun nilam, petani harus mengeluarkan biaya pengadaaan bibit rata-rata Rp Rp 842/Batang. Dalam 1 (Satu) Ha petani membutuhkan bibit rata-rata 22.533 
batang sehingga petani membutuhkan biaya rata-rata untuk pengadaan bibit adalah Rp 18.972.786/Ha/Periode yang didapatkan dari jumlah bibit yang dibutuhkan dikalikan dengan harga bibit.

\section{Biaya Bahan Penunjang}

Biaya bahan penunjang yang digunakan dalam penyediaan bahan baku adalah pupuk dan pestisida. Rincian biaya bahan penunjang dapat dilihat pada Tabel 5.

Tabel 5. Biaya Bahan Penujang Dalam Penyediaan Bahan Baku

\begin{tabular}{|c|c|c|c|c|c|}
\hline No & $\begin{array}{c}\text { Bahan } \\
\text { Penunjang }\end{array}$ & Jumlah & Satuan & Harga (Rp) & Total (Rp) \\
\hline \multirow{5}{*}{1} & \multicolumn{5}{|l|}{ Pupuk } \\
\hline & a. Urea & 61,3 & $\mathrm{Kg}$ & 1.722 & 105.610 \\
\hline & b. NPK & 101,3 & $\mathrm{Kg}$ & 9.000 & 911.970 \\
\hline & c. $\mathrm{KCL}$ & 13,3 & $\mathrm{Kg}$ & 3.500 & 46.655 \\
\hline & d. SP36 & 7,5 & $\mathrm{Kg}$ & 2.000 & 15.000 \\
\hline \multirow{5}{*}{2} & \multicolumn{5}{|l|}{ Pestisida: } \\
\hline & a. Decis & 0,2 & Botol & 25.000 & 4.250 \\
\hline & b. Sprint & 0,2 & Botol & 25.000 & 4.250 \\
\hline & c. Gandasil & 0,2 & Botol & 60.000 & 10.200 \\
\hline & d. Gromosom & 0,2 & Botol & 70.000 & 11.900 \\
\hline \multicolumn{5}{|c|}{ Jumlah } & 1.109 .835 \\
\hline
\end{tabular}

Sumber : Data Primer Diolah (2016)

Dari tabel di atas dapat dilihat bahwa ada 2 jenis bahan penunjang dalam penyedian bahan baku daun nilam yaitu pupuk dan pestisida. Biaya penunjang tertinggi ada pada penggunaan pupuk NPK yaitu Rp 911.970/Ha/Periode. Hal ini disebabkan karena harga NPK yang mencapai $\mathrm{Rp} \mathrm{9.000/Kg} \mathrm{sedangkan} \mathrm{biaya} \mathrm{penunjang} \mathrm{terendah} \mathrm{adalah} \mathrm{pada} \mathrm{penggunaan}$ pestisida Decis dan Sprint yang digunakan untuk zat pengatur tumbuh (ZPT) dan daun yaitu Rp 4.250/Ha/Periode.

\section{Biaya Tenaga Kerja}

Dalam usaha penyediaan bahan baku, tenaga kerja merupakan salah satu ujung tombak dalam menentukan keberhasilan usaha penyediaan bahan baku untuk mencapai hasil yang optimal. Untuk rincian biaya tenaga kerja dapat dilihat pada Tabel 7.

Dari Tabel 7 diatas dapat diketahui bahwa biaya tenaga kerja yang dikeluarkan petani sesuai dengan pekerjaan yang dikerjakan oleh tenaga kerja. Semakin berat suatu pekerjaan maka semakin tinggi upah yang dibayar petani. Upah tertinggi yang harus dibayar petani adalah untuk pengolahan tanah yaitu rata-rata $\mathrm{Rp}$ 5.050.000/Ha/Periode. Sedangkan penggunaan tenaga kerja tertinggi adalah dalam hal penyiangan gulma yaitu 7.17 $\mathrm{HOK} / \mathrm{Ha} /$ Periode, hal disebabkan kegiatan penyiangan harus dilakukan 5 kali dalam satu periode, dalam satu kali penyiangan petani membutuhkan 1,4 HOK tenaga kerja rata-rata biaya tenaga kerja yang dikeluarkan petani adalah Rp 231.227,10/HOK.

Tabel 7. Biaya Tenaga Kerja Dalam Pengadaan Bahan Baku

\begin{tabular}{|l|c|c|c|c|c|}
\hline No & Tenaga Kerja & Rerata & Satuan & $\begin{array}{c}\text { Rerata Upah } \\
(\mathrm{Rp} / \mathrm{HOK})\end{array}$ & Total (Rp) \\
\hline
\end{tabular}




\begin{tabular}{|r|l|r|r|r|r|}
\hline 1 & Pengangkutan Bibit & 1,67 & HOK & 240,000 & 400.000 \\
\hline 2 & Olah Tanah & 3,33 & HOK & 345,000 & 1.150 .000 \\
\hline 3 & Pemupukan & 2,17 & HOK & 346.154 & 750.000 \\
\hline 4 & Penyiangan Gulma & 7,17 & HOK & 83.721 & 600.000 \\
\hline 5 & Pemanenan & 2,83 & HOK & 247.059 & 700.000 \\
\hline 6 & $\begin{array}{l}\text { Pengangkutan Daun } \\
\text { Nilam Basah }\end{array}$ & 1,83 & HOK & 218.182 & 400.000 \\
\hline 7 & Pencacahan & 2,17 & HOK & 323.077 & 700.000 \\
\hline 8 & Penyemprotan & 0,67 & HOK & 525.000 & 350.000 \\
\hline \multicolumn{2}{|l|}{ Rata-Rata } & 21,84 & HOK & 231.227 & 5.050 .000 \\
\hline
\end{tabular}

\section{Sumber : Data Primer (Diolah) 2016}

\section{Biaya Produksi}

Biaya produksi adalah seluruh penggunaan biaya untuk memperoleh bahan baku. Adapun penggunaan biaya dalam penyediaan bahan baku meliputi biaya tetap dan biaya variabel. Rincian biaya dalam penyediaan bahan baku dapat dilihat pada tabel 8 .

Tabel 8. Penggunaan Biaya Dalam Penyedian Bahan Baku

\begin{tabular}{|r|l|r|}
\hline No & \multicolumn{1}{|c|}{ Jenis Biaya } & Total Biaya (Rp) \\
\hline 1 & Biaya Tetap & \\
\hline & a. Biaya Penyusutan Peralatan & 125.225 \\
\hline 2 & Biaya Varibel & \\
\hline & a. Biaya Pengadaan Bibit & 18.965 .125 \\
\hline & b. Biaya bahan penunjang & 1.109 .835 \\
\hline & c. Biaya Tenaga Kerja & 5.050 .000 \\
\hline & TOTAL & 25.256 .185 \\
\hline
\end{tabular}

Sumber : Data Primer (Diolah), 2016

Dari Tabel diatas dapat dilihat bahwa total biaya tetap yang dikeluarkan dalam proses pengadaan bahan baku rata-rata Rp125.225/Periode, sedangkan biaya variabel rata-rata adalah Rp 25.124.960/Periode. Biaya yang digunakan ini adalah untuk mendapatkan hasil daun nilam kering rata-rata adalah $13.975,93 \mathrm{Kg}$.

\section{Jumlah Produksi Bahan Baku}

Produksi yang dimaksud adalah besarnya hasil dari proses pengadaan bahan baku yang dihitung dalam satuan Kilo Gram. Dari hasil penelitian diketahui bahwa dari segala proses 
yang telah dijelaskan diatas, akan memperoleh daun nilam kering sebesar 13.974,93 $\mathrm{Kg} / \mathrm{Ha} /$ Periode.

\section{Penetapan Harga Bahan Baku}

Harga merupakan ukuran dari nilai barang-barang atau jasa-jasa yang telah diberikan. Harga merupakan sesuatu yang sangat mendasar bagi para pembeli maupun penjual. Penetapan harga merupakan masalah yang sangat mendasar dari suatu usaha. Penetapan harga bahan baku (daun nilam kering) adalah dengan cara membagikan seluruh biaya produksi pengadaan bahan baku dibagikan dengan jumlah daun nilam kering yang dihasilkan maka akan diperoleh harga rata-rata sebesar Rp 1.807/Kg.

\section{Analisis Keuntungan Dari Penjualan Daun Nilam Kering}

Pada pembahasan ini diketahui bahwa harga daun nilam kering yang dibudidayakan oleh petani itu sendiri adalah rata-rata sebesar Rp 1.807/Kg. Harga pasar unutuk daun nilam kering rata-rata pada saat penelitian adalah $\mathrm{Rp} 3.000 / \mathrm{Kg}$ yang berarti bahwa jika petani nilam menjual daun nilam kering kepada Agen akan memperoleh keuntungan sebesar Rp 1.193/Kg daun nilam kering. Dengan perhitungan analisis keuntungan untuk bahan baku yang dibudidayakan oleh petani itu sendiri adalah :

$$
\begin{gathered}
\pi_{D N K}=T R-T C \\
\pi_{D N K}=41.924 .790-25.256 .185 \\
\pi_{D N K}=16.668 .605 \\
\pi_{D N K}=\frac{16.668 .605}{13.974,93} \\
\pi_{D N K}=R p 1.193 / \mathrm{Kg}
\end{gathered}
$$

Dari hasil analisis menunjukkan bahwa keuntungan yang diperoleh petani dari penjualan daun nilam kering adalah sebesar Rp 1.193/ Kg yang berarti bahwa setiap penjualan satu kilogram daun nilam kering akan memperoleh keuntungan sebesar $66 \%$ dari biaya yang dikeluarkan petani.

\section{Prosessing Minyak Nilam}

Teknik penyulingan yang digunakan pada daerah penelitian adalah dengan cara penguapan. Caranya yang biasa dilakukan petani adalah dengan memasukkan daun nilam kering sebanyak $144 \mathrm{Kg}$ untuk satu kali ronde penyulingan akan memperoleh minyak nilam sebanyak $2.4 \mathrm{Kg}$. Dari hasil ini kita ketahui bahwa rendemen minyak nilam di Kabupaten Aceh Jaya adalah $1,71 \%$. Setiap satu kali ronde penyulingan petani akan membutuhkan waktu selama 3-4 jam.

\section{Penggunaan Biaya Dalam Proses Penyulingan Minyak Nilam}

Penggunaan biaya dalam penyulingan minyak nilam sama dengan penggunaan biaya dalam penyediaan bahan baku seperti yang dijelaskan diatas yaitu seluruh biaya yang dikeluarkan petani dalam usaha penyulingan minyak nilam. Biaya yang dimaksud adalah biaya tetap dan biaya variabel. Adapun biaya tetap meliputi biaya penyusutan alat sedangkan biaya variabel meliputi biaya bahan baku, biaya penunjang dan biaya tenaga kerja.

\section{Biaya Tetap}

Biaya tetap merupakan biaya yang dikeluarkan petani, tetapi tidak tergantung pada jumlah outuput yang dihasilkan. Biaya tetap yang dimaksud dalam penelitian adalah biaya penyusutan alat yang digunakan dalam proses penyulingan minyak nilam yang diukur dengan satuan Rp/Tahun. Adapun penggunaan biaya penyusutan alat dapat dilihat pada Tabel 9.

Tabel 9. Biaya Penyusutan Alat Dalam Proses Penyulingan Minyak Nilam

\begin{tabular}{|c|l|c|}
\hline No & \multicolumn{1}{|c|}{ Peralatan } & Biaya Penyusutan (Rp/Periode) \\
\hline 1 & Ketel Penyulingan & 666.667 \\
\hline
\end{tabular}




\begin{tabular}{|r|l|r|}
2 & Ketel Air & 53.333 \\
\hline 3 & Mesin Air & 64.000 \\
\hline 4 & Pipa Pendingin & 53.333 \\
\hline 5 & Bak Pendingin & 155.556 \\
\hline 6 & Tungku & 4.667 \\
\hline 7 & Jambo Penyulingan & 400.000 \\
\hline 8 & Pipa Pembuangan & 10.667 \\
\hline \multicolumn{2}{|c|}{ Jumlah } & 1.408 .222 \\
\hline
\end{tabular}

Sumber : Data Primer (Diolah), 2016

Dari tabel diatas dapat dilihat bahwa biaya penyusutan tertinggi ada pada ketel penyulingan. Hal ini disebabkan oleh harga ketel penyulingan yang juga tinggi yaitu Rp 5.000.000/Unit dengan umur ekonomis 5 tahun sehingga diperoleh biaya penyusutan sebesar Rp 666.667/Periode. Sedangkan alat-alat yang lain memiliki harga yang lebih rendah dan umur ekonomis yang sama dengan ketel penyulingan sehingga biaya penyusutan alat menjadi Biaya Variabel

Biaya variabel adalah Biaya variabel adalah biaya-biaya yang dikeluarkan petani yang tergantung pada jumlah produksi yang dihasilkan. Adapun komponen biaya variabel dalam proses penyulingan minyak nilam adalah biaya bahan baku, biaya bahan penunjang dan upah tenaga kerja.

\section{Biaya Bahan Baku}

Bahan baku merupakan daun nilam kering yang diproses langsung oleh petani itu sendiri. Namun untuk menghitung nilai tambah dari daun nilam kering menjadi minyak nilam maka harus ada penetapan harga dasar dari bahan baku itu endiri yaitu sebesar Rp 1.807/Kg. Dalam satu Hektar lahan petani akan menghasilkan daun nilam kering sebanyak 13.974,93 Kg. Sehingga petani membutuh biaya untuk bahan baku sebesar Rp 25.250.183. Biaya ini adalah hasil kali harga bahan baku dengan jumlah bahan baku yang di butuhkan.

\section{Biaya Bahan Penunjang}

Biaya bahan penunjang yang digunakan dalam penyulingan minyak nilam adalah air dan kayu bakar. Rincian biaya bahan penunjang sebagai berikut:

Tabel 10. Biaya Bahan Penunjang Dalam Proses Penyulingan Minyak Nilam

\begin{tabular}{|c|l|c|c|r|}
\hline No & Bahan Penunjang & Jumlah & Satuan & \multicolumn{2}{c|}{ Total Biaya (Rp) } \\
\hline 1 & Kayu Bakar & 4 & Kubik & 3.600 \\
\hline 2 & Air & 32 & Liter & 603.623 \\
\hline \multicolumn{2}{|c}{ Jumlah } \\
\hline
\end{tabular}

Sumber : Data Primer (Diolah), 2016

Dari Tabel diatas dapat kita ketahui bahwa bahan penunjang dalam penyulingan minyak nilam hanya ada 2, yaitu kayu bakar dan air. Biaya untuk kayu rata-rata adalah sebesar Rp 600.000 dengan jumlah kayu yang digunakan rata-rata berjumlah 4 kubik. Harga kayu per kubik adalah $\mathrm{Rp}$ 150.000. Sedangkan penggunaan air rata-rata 32 Liter dengan harga perliter adalah Rp 113,2 sehingga biaya untuk air adalah Rp 3.623. Total biaya penunjang dalam proses penyulingan minyak nilam adalah Rp 603.623.

\section{Biaya Tenaga Kerja Dalam Proses Penyulingan Minyak Nilam}

Dalam usaha penyulingan minyak nilam, tenaga kerja merupakan salah satu ujung tombak dalam menentukan keberhasilan usaha untuk mencapai hasil yang optimal. Tenaga kerja yang digunakan dalam usaha penyulingan minyak nilam rata-rata 4 HOK/Periode. Upah yang diberikan adalah sesuai dengan hasil penyulingan yang didapatkan yaitu dalam $1 \mathrm{Kg}$ minyak nilam yang dihasilkan oleh 1 HOK maka upahnya adalah 0.5 Ons minyak nilam jika 
dikonfersikan dengan harga minyak nilam maka setiap $1 \mathrm{Kg}$ minyak yang dihasilkan maka upahnya adalah $\mathrm{Rp} 30.000$. Rendemen minyak rata-rata adalah $1.72 \%$ dan bahan baku adalah $13.974,93 \mathrm{Kg}$ maka hasil yang akan diperoleh adalah 239,63 $\mathrm{Kg}$ minyak nilam sehingga biaya tenaga kerja yang harus dibayar petani adalah sebesar Rp 7.188.900/Ha.

\section{Biaya Produksi Proses Penyulingan Minyak Nilam}

Biaya produksi adalah seluruh biaya yang dikeluarkan petani untuk memproduksikan minyak nilam. Adapun penggunaan biaya ini meliputi biaya tetap dan biaya variabel. Rincian biaya dapat dilihat pada Tabel 11.

Tabel 11. Penggunaan Biaya Dalam Proses Penyulingan Minyak Nilam

\begin{tabular}{|c|l|r|}
\hline No & \multicolumn{1}{|c|}{ Jenis Biaya } & Total Biaya \\
\hline 1 & Biaya Tetap & 1.408 .222 \\
\hline & a. Biaya Penyusutan Peralatan & 25.250 .183 \\
\hline 2 & Biaya Varibel & 603.623 \\
\hline & a. Biaya bahan baku & 7.188 .900 \\
\hline & b. Biaya bahan penunjang & 34.450 .928 \\
\hline \multicolumn{2}{|c}{ TOTAL }
\end{tabular}

Sumber : Data Primer (Diolah), 2016

Dari tabel diatas dapat dilihat bahwa total biaya tetap yang dikeluarkan dalam proses penyulingan minyak nilam rata-rata Rp1.408.222/Periode, sedangkan biaya variabel rata-rata adalah Rp 33.042.706/Periode. Total biaya produksi yang dikeluarkan petani dalam proses penyulingan adalah Rp 34.450.928/Periode. Biaya yang banyak dikeluarkan petani adalah untuk bahan baku yaitu mencapai Rp 25.250.183 sehingga diperoleh biaya diluar bahan baku adalah bahan baku adalah Rp 9.200.745/Periode atau Rp658/Kg.

\section{Jumlah Produksi Minyak Nilam}

Produksi yang dimaksud adalah besarnya hasil dari proses penyulingan minyak nilam yang dihitung dalam satuan Kg. Dari hasil penelitian diketahui bahwa rendemen minyak nilam di Kabupaten Aceh Jaya adalah $1.72 \%$ dan daun nilam kering yang dihasilkan dari satu hektar lahan adalah 13.974,93 Kg sehingga dapat dihitung jumlah minyak nilam yang dihasilkan dari proses penyulingan adalah 239,63 Kg/Periode.

\section{Harga Jual dan Nilai Produksi Minyak Nilam}

Harga merupakan ukuran dari nilai barang-barang atau jasa-jasa yang telah diberikan. Harga merupakan sesuatu yang sangat mendasar bagi para pembeli maupun penjual. Penetapan harga jual merupakan masalah yang sangat mendasar dari suatu usaha. Penetapan harga minyak nilam dilokasi penelitian sepenuhnya hak agen. Harga jual yang dimaksud dalam penelitian ini adalah harga jual minyak nilam yang berlaku selama penelitian dan diukur satuan kilo gram. Harga jual minyak nilam pada saat penelitian adalah Rp 600.000/Kg.

Nilai produksi merupakan hasil kali antara jumlah produksi dengan harga jual minyak nilam yang ditetapkan selama penelitian. Besar kecilnya nilai produksi tergantung pada tinggi rendahnya harga jual dan jumlah produksi. Nilai produksi yang dimkasud sama dengan total penerimaan petani. Adapun besarnya produksi minyak nilam dalam sat periode dari hasil satu hektar lahan adalah 239,63 Kg dengan harga jual $\mathrm{Rp} 600.000 / \mathrm{Kg}$ sehingga didapatkan nilai produksi adalah sebesar Rp 143.778.000/Periode.

\section{Analisis Pendapatan Dari Proses Penyulingan Minyak Nilam}

Pendapatan yang dimaksud pada penelitian ini adalah besarnya nilai produksi dikurang dengan biaya produksi yang dikeluarkan oleh petani selama proses produksi berlangsung, 
yang diukur dalam satuan rupiah per periode. Adapun besarnya pendapatan yang diperoleh petani nilam dapat dilihat pada Tabel 12 .

Tabel 12. Total Pendapatan Petani Nilam Di Kabupaten Aceh Jaya

\begin{tabular}{|c|c|r|}
\hline No & Uraian & \multicolumn{2}{|c|}{ Jumlah (Rp/Periode) } \\
\hline 1 & Nilai Produksi & 143.778 .000 \\
\hline 2 & Total Biaya Produksi & 34.450 .928 \\
\hline \multicolumn{2}{|c|}{ Pendapatan } & 109.327 .072 \\
\hline
\end{tabular}

Sumber: Data Primer (Diolah), 2016

Berdasarkan tabel diatas memperlihatkan bahwa pendapatan yang diperoleh petani

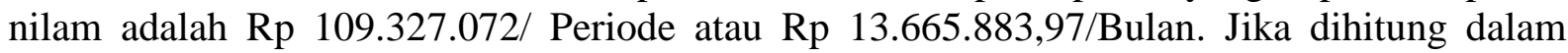
satuan $\mathrm{Kg}$ maka keuntungan yang diperoleh dari proses penyulingan minyak nilam adalah sebesar Rp 7.823 yang berarti bahwa setiap penggunaan satu kilogram daun nilam kering dalam proses penyulingan minyak nilam akan memperoleh keuntungan sebesar $76 \%$ dari biaya yang dikeluarkan petani. Pendapatan ini merupakan pendapatan yang diterima petani setelah dikurangi antara nilai produksi dengan total biaya produksi yang dikeluarkan petani.

Analisis Break Even Point (BEP)

Analisis Break Even Point bertujuan untuk menemukan suatu titik pulang pokok atau biaya yang dikeluarkan sama dengan pendapatan. Untuk mengetahui tingkat pulang pokok bisa dihitung dengan 2 cara, yaitu dengan menghitung berapa jumlah volume yang harus dihasilkan dan dengan cara menghitung dengan berapa harga produk tersebut harus dijual. Dengan menggunkan rumus sebagai berikut :

$$
\begin{gathered}
B E P \text { Volume Produksi }=\frac{\text { Total Biaya }}{\text { Harga Jual }} \\
B E P \text { Volume Produksi }=\frac{34.450 .928}{600.000} \\
\text { BEP Volume Produksi }=57,4 \mathrm{Kg}
\end{gathered}
$$

Atau dengan cara menghitung berapa harga yang harus dijual untuk mendapatkan kurva pulang pokok dengan rumus sebagai berikut:

$$
\begin{gathered}
\text { BEP Harga Produksi }=\frac{\text { Total Biaya }}{\text { Total Produksi }} \\
\text { BEP Harga Produksi }=\frac{34.450 .928}{239,63} \\
\text { BEP Harga Produksi }=\text { Rp } 143.767 / \mathrm{Kg}
\end{gathered}
$$

Hasil analisis BEP volume produksi diperoleh adalah $57,4 \mathrm{Kg}$ sehingga titik pulang pokok akan dicapai pada saat produksi minyak nilam mencapai $57,4 \mathrm{Kg}$. Hal ini berarti bahwa apabila petani hanya mendapatkan minyak nilam 57,4 Kg/Periode, maka petani tidak memperoleh keuntungan dan tidak juga mengalami kerugian. Sedangkan dari hasil analisis BEP harga produksi diperoleh adalah $\mathrm{Rp} 143.767 / \mathrm{Kg}$ sehingga titik pulang pokok akan dicapai pada saat minyak nilam dijual dengan harga Rp 143.676/Kg. Hal ini berarti bahwa apabila petani hanya menjual minyak nilam sebesar $\mathrm{Rp} 143.767 / \mathrm{Kg}$, maka petani tidak memperoleh keuntungan dan tidak juga mengalami kerugian.

\section{Analisis Rentabilitas}

Rentabilitas pada usaha penyulingan minyak nilam yaitu menunjukkan perbandingan antara laba dengan aktiva atau modal yang menghasilkan laba tersebut. Dengan kata lain rentabilitas adalah kemampuan petani nilam untuk menghasilkan laba selama periode tertentu, dan umumnya dirimuskan sebagai:

$$
\text { Rentabilitas }=\frac{L}{M} \times 100 \%
$$




$$
\begin{gathered}
\text { Rentabilitas }=\frac{109.327 .072}{34.450 .928} \times 100 \% \\
\text { Rentabilitas }=31,7 \%
\end{gathered}
$$

Hasil analisis menunjukkan bahwa persentase rentabilitas adalah $31,7 \%$ yang berarti bahwa setiap penggunaan modal sebesar Rp 100 akan memberikan keuntungan sebesar Rp 31,7 dalam proses penyulingan minyak nilam. Nilai rentabilitas sebesar $31,7 \%$ menunjukkan bahwa usaha penyulingan minyak nilam menguntungkan dengan asumsi jika persentase rentabilitas > tingkat bunga yang berlaku maka usaha tersebut akan memberikan keuntungan. Adapun tingkat bunga yang berlaku adalah selama penelitian (Mei 2016) yaitu sebesar 6,75\%.

\section{Analisis Nilai Tambah}

Nilai tambah merupakan penambahan nilai suatu produk sebelum diolah dengan setelah diolah per satuan. Dalam penelitian ini nilai tambah dihitung untuk mengetahui penambahan nilai yang diperoleh dari proses penyulingan minyak nilam dengan menggunakan bahan baku yang dibudidayaan petani itu sendiri dan menggunakan ketel milik pribadi. Sedangkan rentabilitas dihitung untuk melihat prestasi yang dicapai dalam proses pengolahan minyak nilam dan dinyatakan dalam persentase, setelah dibandingkan antara hasil yang dicapai dengan biaya produksi yang digunakan. Semakin besar presentasinya maka semakin tinggi persentase keuntungan dari usaha tersebut, demikian sebaliknya. Nilai tambah dari proses ppenyulingan minyak nilam dapat dihitung dengan menggunakan rumus sebagai berikut:

$$
\begin{gathered}
N T_{D N K}=7.823-1.193 \\
N T_{D N K}=6.630
\end{gathered}
$$

Dengan rasio Nilai Tambah sebagai berikut :

$$
\begin{gathered}
N T_{D N K}(\%)=\frac{N T_{D N K}}{\pi_{D N K}} \times 100 \% \\
N T_{D N K}(\%)=\frac{6.630}{7.823} \times 100 \% \\
N T_{D N K}(\%)=84,75 \%
\end{gathered}
$$

Dari hasil analisis menunjukkan bahwa nilai tambah yang diperoleh adalah bersifat positif yaitu Rp6.630/ Kg dengan rasio nilai tambah 84,75 \% yang berarti selisih antara penjualan daun nilam kering dengan penjualan minyak nilam berbeda sebesar $84,75 \%$ sehingga dapat disimpulkan bahwa setiap penggunaan daun nilam kering dalam proses penyulingan minyak nilam akan mengalami perubahan nilai atau nilai tambah sebesar $\mathrm{Rp}$ 6.630/Kg. Dari hasil rasio nilai tambah diketahui bahwa nilai tambah yang diperoleh petani adalah tinggi, karena menurut Hubeis (1997), rasio nilai tambah dapat digolongkan menjadi 3 yakni dikatakan rendah jika $(<15 \%)$, sedang jika berkisar $(15 \%-40 \%)$ dan tinggi jika $(>40$ $\%)$.

\section{KESIMPULAN DAN SARAN}

Berdasarkan hasil penelitian dan pembahasan, maka dapat diambil kesimpulan sebagai berikut:

Usaha penyulingan minyak nilam menguntungkan bagi petani karena persentase rentabilitas yang diperoleh sebesar $31,7 \%$. Berarti bahwa persentase rentabilitas > tingkat bunga yang berlaku.Adapun tingkat bunga yang berlaku (4,5\%).

Usaha penyulingan minyak nilam memberikan nilai tambah yang diperoleh adalah bersifat positif yaitu Rp6.630/ Kg dengan rasio nilai tambah 84,75 \% yang berarti selisih antara penjualan daun nilam kering dengan penjualan minyak nilam berbeda sebesar $84,75 \%$. Berarti bahwa nilai tambah yang diperoleh petani adalah tinggi, karena rasio nilai tambah $>40 \%$. 
Adapun saran yang dapat diberikan dalam penelitian ini adalah :

Diharapkan kepada Peneliti selanjutnya untuk meneliti perbandingan nilai tambah yang diperoleh petani nilam yang tidak memiliki lahan dan ketel milik pribadi dengan petani nilam yang memiliki lahan dan ketel milik pribadi serta meneliti faktor apa saja yang menyebabkan kurangnya minat petani untuk budidaya tanaman nilam.

\section{DAFTAR PUSTAKA}

Budi, M. 2009. Keragaman Genetik, Heritabilitas dan Korelasi Antar Karakter Kuantitatif Nilam (Pogostemon sp.) Hasil Fusi Protoplas. Industrial Crops Research Journal. 15 (1) : 9-15.

Cahyono, B. 2003. Teknik Budidaya dan Analisis Usaha Tani. Kanisius. Yogyakarta.

Hobir., 2002. Pengaruh selang panen terhadap pertumbuhan dan produksi

Nilam. J. Littri. 8: 103-107.

Hubeis, M. 1997. Menuju Industri Kecil Profesional di Era Globalisasi melalui Pemberdayaan Manajemen Industri. Orasi Ilmiah Guru Besar Tetap Ilmu Manajemen Industri. Fakultas Teknologi Pertanian. Institut Pertanian Bogor. Bogor.

Melati dan D, Rusmin. 2008. Pengaruh Jenis Kemasan Terhadap Mutu dan Pertumbuhan Stek Nilam Berakar (Pogostemon Cablin Benth) Selama Penyimpanan. Industrial Crops Research Journal. 14 (1) : 1-6.

Riyanto, B. 1999. Dasar-dasar Pembelanjaan Perusahaan, Edisi ke empat, BPFE ,Yogyakarta.

Soekartawi, Rusmadi dan Effid. 1993. Resiko dan Ketidakpastian Dalam Agribisnis : Teori dan Aplikasinya, Cetakan Pertama. Raja Grafindo Persada. Jakarta. 